Energy Economics and Policy 1 ENER - The European Network for Energy Economics Research 
Francis McGowan (Ed.)

\section{European Energy Policies in a Changing Environment}

With 28 Tables

\section{Physica-Verlag}




\section{Francis McGowan}

School of European Studies

University of Sussex

Falmer, East Sussex

United Kingdom BN1

ISBN-13:978-3-7908-0951-0 Physica-Verlag Heidelberg

Die Deutsche Bibliothek - CIP-Einheitsaufnahme

MacGowan, Francis:

European energy policies in a changing environment : with 28

tables / Francis McGowan. - Heidelberg : Physica-Verl., 1996

(Energy economics and policy; Vol. 1)

ISBN-13:978-3-7908-0951-0 e-ISBN-13:978-3-642-61492-7

DOI.10.1007/978-3-642-61492-7

NE: GT

This work is subject to copyright. All rights are reserved, whether the whole or part of the material is concerned, specifically the rights of translation, reprinting, reuse of illustrations, recitation, broadcasting, reproduction on microfilms or in other ways, and storage in data banks. Duplication of this publication or parts thereof is only permitted under the provisions of the German Copyright Law of September 9, 1965, in its version of June 24, 1985, and a copyright fee must always be paid. Violations fall under the prosecution act of the German Copyright Law.

C Physica-Verlag Heidelberg 1996

The use of registered names, trademarks, etc. in this publication does not imply, even in the absence of a specific statement, that such names are exempt from the relevant protective laws and regulations and therefore free for general use. 


\section{Preface}

Across the European Union, energy policy remains a highly controversial issue, despite the relative stability of energy markets and the lack of concern of energy availabilities and prices which marked previous debates on the issue. The debates on nuclear power in Germany, on the coal industry in the UK indicate the continuing resonance of energy policy as a source of dispute at the national level. Moreover, while the urgency which the 1970s energy crises brought to policy discussions may no longer exist, the emergence of new issues, such as the environment and economic liberalisation, have offered new challenges for energy policy.

These issues also arise in a European setting. Early in 1995 the European Commission published a Green Paper on Energy Policy - indeed, as the manuscript was completed the Commission was finalising a White Paper - and the issue will be on the agenda of the 1996 Intergovernmental Conference. The outcome of these discussions is far from clear, but there is no doubt that, in one way or another the European Union will help to shape national energy policies for many years to come.

This book aims to review the development of energy policy at both the national and the European levels. On the basis of a series of country studies, the book aims to show how policies have evolved in the post war period (especially the last twenty years). It outlines how governments' roles have changed in the energy sector and assesses the impact of new policy challenges. The interaction between national and European authorities is also considered, along with a more detailed consideration of the problems which European energy policy encounters.

The book has been written by a team of energy policy experts drawn from the European Network for Energy Research (ENER). This network, established for over a decade and funded by the European Commission, brings together energy policy analysis groups from Belgium, Denmark, France, Germany, Italy, the Netherlands, Portugal, Spain and the United Kingdom. The chapters here have been written by members of the longest established institutes: the Fraunhofer Institute for Innovation and Research, Karlsruhe; the Institute for Energy Economics and Policy, Grenoble; the Institute for Energy Research, Milan; and the Science Policy Research Unit, Sussex. This book is intended as the first in a series of ENER publications. 
Although the contributors have debated these issues over many years, there is no common view on how energy policy should develop at the national or the European level. For example, amongst the contributions it is possible to identify those concerned about the absence of a Common European Energy Policy and those who are happy to see such an absence persist. Yet all the contributions strive to inform the debate on energy policy in Europe at both a national and an EU level.

The authors would like to thank their colleagues, both in the ENER network as a whole and in their individual research institutes, for providing a stimulating intellectual environment in which to develop these ideas. The editor would like to thank the authors and colleagues for their support throughout the preparation of this volume. In particular, he would like to thank Catherine Mitchell from the Science Policy Research Unit and Eberhard Jochem from the Fraunhofer Institute for their patient persistence and encouragement. 
Contents

1. Energy Policy in the EU - Diversity or Convergence?

Francis McGowan, University of Sussex

2. French Energy Policy - the Effectiveness and Limitations of Colbertism

Dominique Finon, University of Social Sciences at Grenoble

3. German Energy Policy in Transition

Eberhard Jochem, Edelgard Gruber and Wilhelm Mannsbart, FhG-ISI, Karlsruhe

4. Italian Energy Policy: From Planning to an (Imperfect) Market

Luigi De Paoli, Bocconi University, Milan

5. Ideology and Expediency in British Energy Policy

Francis McGowan, University of Sussex

6. The Future of EU Energy Policy

Dominique Finon and John Surrey, Universities of Grenoble and Sussex 